\title{
Long term dynamics of 2 populations of Prosopis caldenia Burkart
}

\author{
ESTEBAN DUSSART, PAMELA LERNER*, AND RAUL PEINETTI
}

Authors are assistant professors, Facultad de Agronomia Universidad Nacional de La Pampa, cc 300 Santa Rosa (6300) Argentina and (*) Facultad de Ciencias Exactas y Naturales, Universidad Nacional de La Pampa, Uruguay 151 Santa Rosa (6300) Argentina. E-mail: pdlerner@criba.edu.ar

\begin{abstract}
Invasion of pristine grasslands by calden (Prosopis caldenia Burkart), and increased densities of this species in savannas are well-known vegetation changes in the semiarid region of central Argentina although little is known about its rates and patterns. In this paper we studied the relationship between dynamics of 2 representative $\boldsymbol{P}$. caldenia populations and factors that could control the invasion process such as range management, fire events and precipitation regimes. Rates of implantation and spatial patterns are quantified using the present age distribution and dendroecological techniques. The pristine landscapes of the 2 study sites were grassland plains with (Site 2) and without trees (Site 1). The present density of the calden is 586 and 1,259 shrubs/ha in Site 1 and 2, respectively. No evidence of clustering was found at the spatial scale of the study $(p=0.52$, Site 1 and $p$ $=0.08$, Site 2 for $n=112$ ). The ages of sampled individuals ranged from 3 to 65 years in site 1 and 8 to 55 years in Site 2 (only trees with diameter lower than $30 \mathrm{~cm}$ were sampled in Site 2). The importance of cattle as an effective disperser of calden seeds was contirmed, as changes in measured establishment rates coincided fairly well with changes in cattle management. Establishment rates during the period of sheep grazing were 0.99 plant/ha/yr (16 years) in Site 1 and 10 plant/ha/yr (15 years) in Site 2. However, 10 years after the introduction of cattle these values reach $12.7 \mathrm{plant} / \mathrm{ha} / \mathrm{yr}$ and $48.5 \mathrm{plant} / \mathrm{ha} / \mathrm{yr}$, respectively. One fire event occurred at each site (1980 in Site 1 and 1964 at Site 2). This factor did not change the density trend at Site 1 , and at Site 2 it coincided with cattle introduction and caused an impressive increase in tree establishment. Fire was not an effective means of controlling $P$. caldenia populations. No relationship was found between population dynamics and available precipitation data.
\end{abstract}

Key Words: age structure, woody invasion, population dynamics, dendroecology, resprouting, recruitment, woodland, Prosopis sp.

Semi-arid savannas are distributed in several parts of the world. This term includes systems with different structure and function, produced by different rainfall, soil, fire, and herbivory regimes

\footnotetext{
Manuscript accepted 6 Dec. 1997

Authors thank Evelyne De Conninck for her aid during field work; Ing. Alberto Sosa, Dr. A. M. Gimenez de Bolzón and Ing. Beatriz Fernandez for their technical assistance and Dr. J.F. Ledent and Dr. A. Cibils, for their critical review of a draft of the manuscript. We also thank Mr. Stefanazzi and Mr, Gorondi and their families, owners of the sampling sites, for their assistance and hospitality.
}

\section{Resumen}

Los cambios más importantes registrados en la distribución del calden (Prosopis caldenia Burkart) en la región semiárida central de Argentina, incluyen el aumento de la densidad de esta especie y la invasión de pastizales naturales. Los factores causales y la dinámica de estos cambios no han sido detalladamente estudiados. En este trabajo se relaciona la dinámica de dos poblaciones de calden con factores tales como manejo, fuego y precipitaciones. Se eligieron como áreas de estudios una planicie cuya vegetación original era un pastizal (Sitio 1) y un bosque de calden que originalmente fue una sabana (Sitio 2). En cada Sitio se determinaron los patrones espaciales en base a transectas y las tasas de implantación las cuales fueron inferidas por dendroecologla. Las densidades estimadas fueron 586 y 1259 plantas/ha, para el Sitio 1 y 2 respectivamente. No se encontraron evidencias de agrupamiento para la escala espacial de este estudio $(p=0.52$, Sitio 1 y $\mathrm{p}=0.08$, Sitio 2 para $\mathrm{n}=112$ ). Las edades de los individuos muestreados comprendieron un rango de 3 a 65 años en el Sítio 1 y de 8 a 55 años en el Sitio 2 (en este sitio 2 solo fueron muestreadas las plantas con diámetro menor de $30 \mathrm{~cm}$ ). Primariamente los dos sitios fueron utilizados para crìa de ovinos; durante ese perÌ̀do, las tasas de establecimiento fueron 0.99 plantas/ha/año (16 años) en el Sitio 1, y 10 plantas/ha/año (15 años) en el sitio 2. Posteriormente luego de diez años desde la introducción del ganado vacuno, las tasas ascendieron a 12.7 y 48.5 plantas/ha/año respectivamente. Un evento de fuego fue registrado en cada Sitio (1980 en el Sitio 1 y 1964 en el Sitiu 2) pero este factor no alteró la tendencia ascendente de la densidad. En el Sitio 2 el incendio fue contemporáneo con la introducción del ganado y coincide a su vez con un importante incremento en el establecimiento. No se encontró relación entre la dinámica de la población de calden y las fluctuaciones en la precipitación anual o estacional. Las variaciones registradas en las tasas de establecimiento coincidieron con cambios en el manejo ganadero, confirmando la importancia del ganado en la dispersión de las semillas de calden.

within different time frames (Skarpe 1992). African and Asian savannas have developed under a long and continuous history of large herbivore foraging whereas Australian and South American savannas lost most of their large herbivores during the last ca. 50,000 years (Skarpe 1992). In all these areas, however, savannas have undergone remarkably similar changes in vegetation structure and composition since the late 1800's (Walker et al. 1981, McNaugthon 1992) following the introduction of domestic cattle or sheep (Walker et al. 1981). The most common change has 
been the transformation of open grassland into stable woodland or shrubland vegetation. This process has been recorded and studied in different parts of the world and especially in the USA where mesquite has taken over large areas of grasslands (Archer 1995, Bahre and Shelton 1993). Woody weed encroachment has also occurred in Africa, Australia, and South America (Archer 1989, 1995, Skarpe 1992).

Similar vegetation changes have also occurred in the phytogeographic District of the Caldenal (Cabrera and Willink 1973) in central Argentine. This area of about $40,000 \mathrm{~km}^{2}$ was originally covered by open forests dominated by Prosopis caldenia Burkart (calden), concentrated mostly in valleys, and by grasslands on dunes and plateaux (Cano et al. 1980). When farming began in the early 20 th century, the landscape was covered with stands of large or medium sized calden trees surrounded by a matrix of shortgrasses (W.C. Hickey and O.A. Knudtsen, unpublished data). Areas with high densities of young calden trees, or impenetrable jungles with high densities of calden and other brushes such as Condalia microphylla Cav., Schinus fasciculatus (Griseb.) Johnston and Geoffrea decorticans (Gill.ex Hook. et Arnott) Burkart were unknown. These vegetation types now frequently replace the formerly forested areas as well as the neighboring grassy plain or undulating dunes which were once void of woody plants. In this study we examined the disturbances associated with these changes in the specific case of $2 P$. caldenia populations in La Pampa.

The role of different disturbances that could favor the transition from savanna grassland to shrubland or woodland has been studied in La Pampa (Pelaez et al. 1992, Peinetti et al. 1993, Llorens 1995), as well as in other semi-arid savannas (Westoby et al. 1989, McNaugthon 1992, Skarpe 1992, Bahre and Shelton 1993, Archer 1995). The current structure of most semi-arid savannas, particularly the mixture of herbaceous and trees or shrub layers, is normally explained as a function of changes in climate (specifically water regime), soil nutrients, fire, and herbivory. Howcver, little evidence is available to demonstrate these processes by direct assessment of vegetational changes taking into account the dynamics of woody population (Archer 1990). The past dynamics of a woody plant population can be inferred from its age structure using dendrological techniques (Harper 1990).

$P$. caldenia fits well to this methodology since its age can be determincd by its annual growth rings (Peinetti et al. 1994) as in other species of the genus (Villalba 1985, Flinn et al. 1994). Resprouting is a common feature of $P$. caldenia, and disturbances not only lead to changes in tree density but also alter the structural features of the whole population through a shift in the modular growth of the individuals. This has been observed in $P$. caldenia when the main stem dies and the bud crown around the stem base sprouts following disturbance such as clearing or fire (Llorens 1995). The age of the stump sprouts may differ from the age of the genets. The age structure of such regrowth should reflect the disturbance history of the population. Consequently, we considered the ages of both genets and resprouts in assessing vegetation changes in our study.

The objective of the experiment reported in this paper was to determine the temporal patterns of densities of both genets and resprouts of 2 populations of $P$. caldenia, and their association with factors of disturbance such as management, fire events, and precipitation variations.

\section{Materials and Methods}

Calden population dynamics was studied at 2 sites with contrasting characteristics (Table 1) even though both of them presented high percentages of young $P$. caldenia plants. The major difference between the 2 sites was that at Site 1, $P$. caldenia colonized a previously unoccupied area, whereas at Site 2 there was enhanced recruitment of the species. Sampling was carried out in a 42 ha area at Site 1 and 44 ha at Site 2, during the months of August to September 1993, before the beginning of $P$. caldenia cambial activity. Sixteen transects, each $150 \mathrm{~m}$, were randomly placed in each site, and 7 sampling points were randomly located along each transect. A minimum separation of $8 \mathrm{~m}$ between points was imposed to avoid double sampling of the same individual. At all points, 4 individuals were chosen using the point centered quarter method (Cottam and Curtis 1956), to determine the density of living individuals, and the percentage of dead and resprouting plants. Mean densities calculated from each transect within a site were compared using a 1 way ANOVA random effects model, and significant differences were interpreted as a sign of clustering.

Age distribution was inferred by sampling the individual nearest to the quarter center in each sampling point $(n=112)$. Individuals were cut at the crown level to obtain a $2-5 \mathrm{~cm}$ thick section that was returned to the laboratory for crossdating. An additional section was extracted from the base of the thickest stem in the case of resprouting individuals, to record it as the oldest regrowth. A sampling restriction was imposed in Site 2 because of the presence of old individuals with basal diameter greater than $30 \mathrm{~cm}$. These individuals were not sampled for crossdating but were recorded as the oldest individual at the site. Cross sections $>1 \mathrm{~cm}$ in diameter were flattened with a jack plane, and sanded using an electric sander with successively finer grained sandpaper ( 80 through 600 grit). Dust was regularly removed from vessel cells with a vacuum cleaner. After sanding, rings were counted under a Stereo Wild Mtr 22 magnifier $(0.9$ to $4 \mathrm{X}$ ) by 2 independent observers in the same 2-3 radii per cross section, to rectify for false or missing rings. When differences among ring counts between radii could not be resolved because of fire scars or anomalous wood near the pith or branching zones, an average number of rings of 2-3 radii was used. Mounts prepared with cross sections $<1 \mathrm{~cm}$ diameter were dated with the help of an ANIOL ring-count computerized device, which includes a chronology program for data processing.

The temporal pattern of plant establishment at each site was constructed with the crossdating data registered at the crown level, considering each age as the age of the genet. This method assumed that it is possible to quantify the total numbers of individuals present, and the way these numbers varied with time, without quantifying patterns of birth and death. This limited the scope of the study, but not its usefulness (see Begon et al. 1990). The temporal changes in plant establishment were visually contrasted with the history of management, fire records and precipitation data to look for simultaneous events. An additional pattern of age distribution was constructed at each site by considering the age of the aerial part that included the age taken at crown level, when the sample was not resprouting, and the ages of the thickest stem in the other cases. Differences between the age of establishment and age of aerial part pattern were taken as evidence of disturbances. 
Table 1. Characteristics of the 2 study sites.

\begin{tabular}{|c|c|c|}
\hline & Site 1 & Site 2 \\
\hline Location & $\begin{array}{l}37^{\circ} 09^{\prime} \mathrm{S}, 64^{\circ} 49^{\prime} \mathrm{W} \\
30 \mathrm{~km} \text { W from Quehue - La Pampa }\end{array}$ & $\begin{array}{l}36^{\circ} 12^{\prime} \mathrm{S}, 64^{\circ} 51^{\prime} \mathrm{W} \\
20 \mathrm{~km} \text { E from Luan Toro - La Pampa }\end{array}$ \\
\hline Physiographic Sub-Regions(*) & $\begin{array}{l}\text { upland plain surrounded by valleys } \\
\text { altitude } 300 \mathrm{~m}\end{array}$ & $\begin{array}{l}\text { gently rolling terrain surrounded by hills } \\
\text { and sandy accumulations, altitude } 250 \mathrm{~m}\end{array}$ \\
\hline Climate $(* *)$ & $\begin{array}{l}\text { Dry continental } \\
\text { average annual temperature: } 16^{\circ} \mathrm{C} \\
\text { annual precipitation: } 550-600 \mathrm{~mm} \\
\text { frost-free period: } 170 \text { days } \\
\text { water deficit: } 250-300 \mathrm{~mm}\end{array}$ & $\begin{array}{l}\text { Dry continental } \\
\text { average annual temperature: } 16^{\circ} \mathrm{C} \\
\text { annual precipitation: } 550-600 \mathrm{~mm} \\
\text { frost-free period: } 200 \text { days } \\
\text { water deficit: } 250-300 \mathrm{~mm}\end{array}$ \\
\hline Vegetation $(* * *)$ & $\begin{array}{l}\text { Shrub Layer }(<5 \mathrm{~m}) \text { : dominated by } \\
\text { Prosopis caldenia Burkart but also } \\
\text { contains Prosopis flexuosa D.C. } \\
\text { Condalia microphylla Cav. } \\
\text { Herbaceous layer: dominated by } \\
\text { Stipa eriostachya H.B.K., Stipa } \\
\text { tenuissima Trin., Hyalis argentea Don. }\end{array}$ & $\begin{array}{l}\text { Tree layer }(>5 \mathrm{~m}) \text { : Prosopis caldenia Burkart } \\
\text { Shrub layer }(<5 \mathrm{~m}) \text { : dominated by } \\
\text { Prosopis caldenia Burkhart but also } \\
\text { contains Prosopis flexuosa D.C. } \\
\text { Condalia microphylla Cav, Lycium } \\
\text { chilense Miers. } \\
\text { Herbaceous layer: Stipa tenuissima } \\
\text { Trin., S. eriostachya H.B.K., } \\
\text { S. brachychaeta Godr., Poa ligularis Nees ap. } \\
\text { Steud., Piptochaetium napostaense (Speg) } \\
\text { Hack, Baccharis gilliesii A. Gray. }\end{array}$ \\
\hline Soil $(* * *)$ & $\begin{array}{l}\text { Entic haplustol } \\
\text { sandy texture } \\
\text { little organic matter } \\
\text { excessive permeability } \\
\text { petrocalcic horizon at about } 0.5 \mathrm{~m} \\
\text { water table: } 85 \mathrm{~m}\end{array}$ & $\begin{array}{l}\text { Entic haplustol } \\
\text { sandy to silty clay loam texture } \\
\text { moderate organic matter } \\
\text { well drained } \\
\text { petrocalcic horizon at } 1 \text { to } 1.5 \mathrm{~m} \\
\text { water table: } 75 \mathrm{~m}\end{array}$ \\
\hline
\end{tabular}

$\left.{ }^{*}\right)$ Salazar Lea Plaza, J.C. (1980)

$(* *)$ Casagrande, G. and H.A. Conti (1980)

$(* * *)$ registered in each study site

The population density for each age class was inferred using frequency for each age class, and present total density (Harper 1990, Young and Evans 1981). The historical events of the 2 study sites were determined by interviewing land-owners and old timers that lived there before. We used precipitation data from meteorological stations of the "Dirección de estadísticas y censos - Gobierno de la provincia de La Pampa - Argentina", Quehue station (located $30 \mathrm{~km}$ from Site 1), and Tte. Gral. Emilio Mitre (situated $10 \mathrm{~km}$ from Site 2). The growing season data of $P$. caldenia were analyzed following the amount of precipitation received during the 6 month growing season (October to March). Drought and wet periods were defined by comparing 10-year running means with the mean of the whole period (Bahre and Shelton 1993).

\section{Results}

\section{Historical Events \\ Management History}

Site 1 was a pristine grassland plain without trees, dominated by the valuable grasses Stipa tenuis Phil, and Piptochaetium napostaense (Speg.) Hack. (flechillas), and surrounded by valleys which supported mature calden forests. This upland site was first colonized, about 90 years ago, for wheat monoculture in small areas (about $50 \mathrm{ha}$ ), until the drought period and economic crisis of the 1930's (Fig. 1 A). After the last tilling, which occurred about 1933, livestock were brought to the site. The sampling site was located in a field previously managed as a single enclosure
(2,500 ha), including part of the forested valley (distance of 1 $\mathrm{km})$. About 5,000 sheep plus a few (20-40) cows and horses were grazed in the area up until 1949, when the lessee family became owner of the field and shifted from sheep to cattle ranching. The site was heavily grazed which is evident by the present vegetation. Statistics suggest that it has been usually stocked with about 1 bovine Livestock Unit (L.U.)/5 ha, whereas local agronomists assess proper use for these fields at no more than 1 L.U./10 ha. In 1962 , as a result of ownership division, the upland fields were fenced and cattle were no longer allowed to move between the valley and our research site. Only one fire event (in summer 1980 ) is mentioned in the records of the "Dirección de Defensa Civil Provincial", as well as by old-timers. This was an important fire because $41 \%$ of individuals $>13$ years-old showed fire marks on their main stem for that year. Wood clearing was never done in this place, except for some exploitation for fuel by the present owner's family.

Site 2 was a pristine savanna parkland, supporting a grassy matrix dominated by Poa ligularis Nees ap. Steud. and Piptochaetium napostaense (Speg.) Hack., which surrounded the large but scarce $P$. caldenia plants. Today, a dense woody stand covers nearly a $100 \%$ of the site. Two logging periods were recorded for this site, 1914-1915 and 1945-1950 (Fig 1 B), but no data of logging intensity are available other than that sawmill activities were high. As agriculture was forbidden by law in this region, stems had to be cut at $60 \mathrm{~cm}$ aboveground. Light exploitation for the production of fencing posts (about $6 / \mathrm{ha}$ ) has been carried out every 10 years since 1975 . In addition to these logging activities, sheep were grazed at high stocking rates from 1945 to 


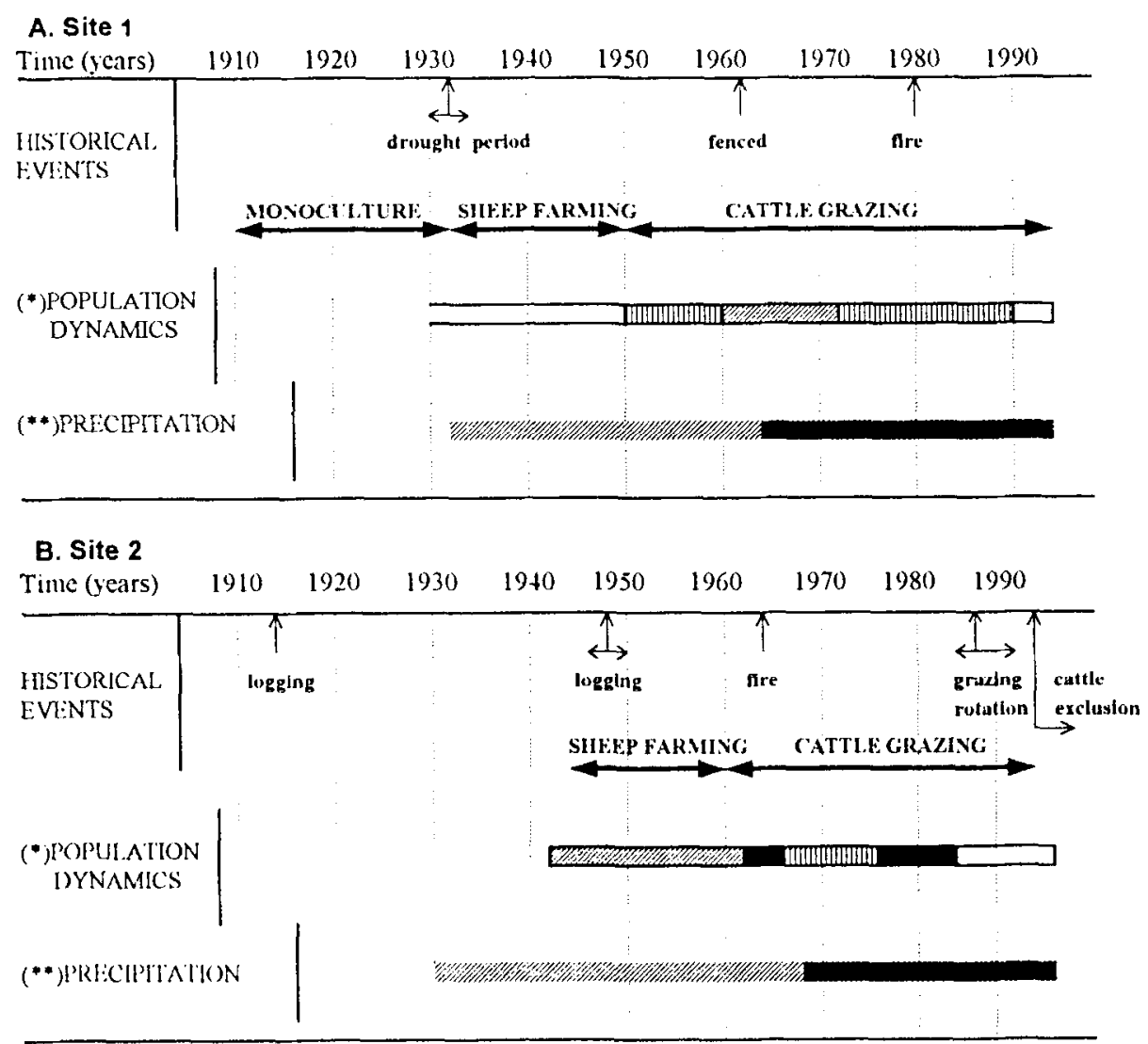

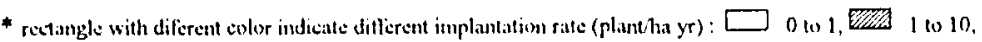
UIIIII) $10(1620$ and. $>20$

* har with difletent coler indicate dry or wet periesl considering the relation between mean precipitation of

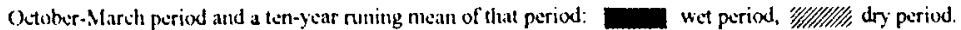

Fig. 1. General scheme comparing historical events, P. caldenia populations dynamics and precipitation of the 2 study sites. (A) Site 1 , (B) Site 2.

1960. Cattle raising began at Site 2 between 1968 and 1980 with stocking rates as high as 1 bovine L.U./2 ha recorded. This is 3 times the proper use suggested by local expert advice (Nazar Anchorena 1988). From 1985 until 1992, the area was managed using a rotation grazing scheme. A stocking rate close to 1 L.U/5 ha was maintained, especially during the calden pod shedding period in late summer (March-April). The herd was wintered on grass in other fields. Since 1993, cattle have been excluded from the site. Old timers remember a very big fire in 1964 .

\section{Precipitation}

At both research sites, a relatively dry period lasted from the beginning of the 1930 's, until the end of the 1960's. The amount of precipitation per growing season has increased gradually since then (Fig $1 \mathrm{~A}$ and $1 \mathrm{~B}$ ).

\section{Population Features \\ Density and Spatial Distribution}

Density of living individuals was lower in Site $1(586 \pm 34$ shrub/ha) than in Site $2(1259 \pm 129$ shrub/ha). Establishment and resprouting stimuli, such as seed dispersal by cattle or fire, appear to have acted homogeneously at both sites as distribution of indi- viduals in space showed no evidence of clustering at either site ( $\mathrm{p}$ $=0.52$, site 1 and $p=0.08$, site $2 ; n=112$ in both cases; Bartlett's tests for heteroscedacity were not significant). Although there were site differences, patterns of spatial distribution coincide at the scale of the study (Kershaw 1973). While the sampling design used was more suited to determining age structures than spatial distributions (Matteucci and Colma 1982), strong clustering should have been detected by the method used if present. High percentages of resprouting were found mainly at site 1 where values reached $66 \% \pm 4.9 \%$, compared to $36 \% \pm 4.5 \%$ at Site $2(\mathrm{n}=$ 112). The percentages of dead individuals were low at both sites (5.2\% and $1.1 \%$, respectively).

\section{Age Distribution}

The age distribution of sampled individuals ranged from 3 to 65 years at Site 1 and from 8 to 55 years at Site 2, for trees with stem basal diameter $<30 \mathrm{~cm}$. Trees larger than this were not sampled. No evidence of age distribution clustering was found at either site by comparing mean establishment age of individuals between transects ( $p=0.09$, for Site 1 and $p=0.40$, for Site 2 ). The age distribution pattern of the genets showed that recruitment was common after the 1950's at Site 1 and the 1960's at Site 2 
(A)

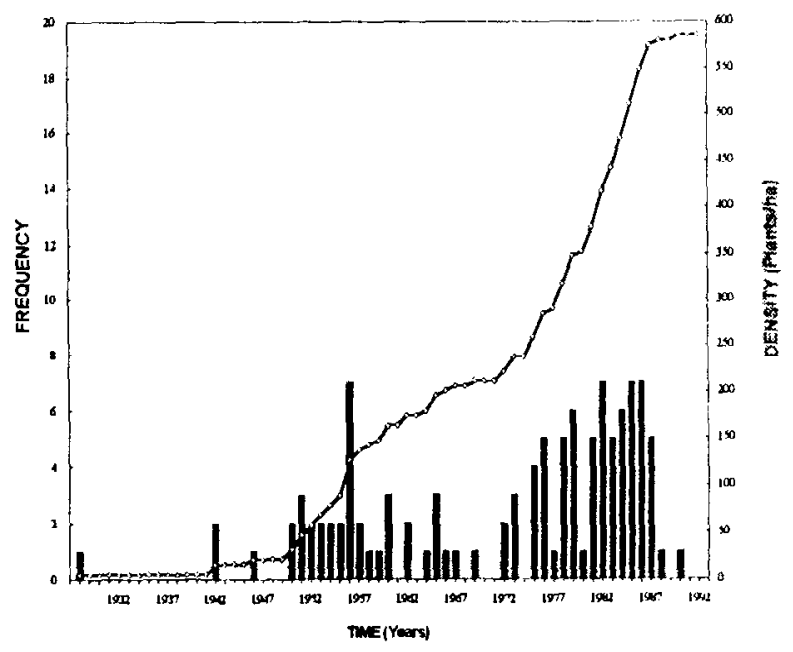

(1)

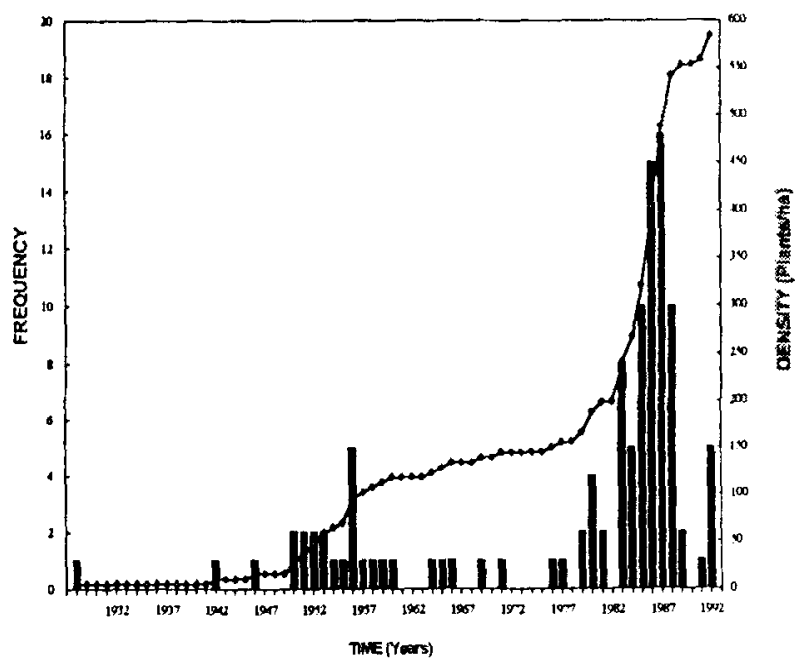

Fig. 2. Density (line) and frequency (bars) of age of establishment (A) and age of aerial part (B) of Site 1.

(Fig 2A and 3A). A noticeable absence of the younger cohorts at both sites could be a consequence of sampling error caused by the timing of the sampling. Sampling was carried out during winter when the calden is dormant, and winter forbs and tall grasses made it difficult to find juvenile $P$. caldenia plants.

The most important inflections in the density curves were used to determine periods of recruitment. Based on this criterion, we differentiated 5 periods of recruitment at each site (Fig. 2A and 3A). For Site 1, a period that lasted until 1949 is characterized by low recruitment $(0.96 \mathrm{plant} / \mathrm{ha} / \mathrm{yr})$ and coincided with the periods of agriculture and sheep farming (Fig 1A). A second recruitment period occurred when cattle were introduced $(13$ plant/ha/yr between 1950 to 1960). The relative decrease in recruitment registered afterwards (4.3 plant/ha/yr, between 1961 to 1971) coincided almost exactly with the fencing of the site, which prevented cattle from grazing calden pods in the forested neighboring valley. Another invading phase started in 1972 and lasted until 1990 (with a mean of $19.7 \mathrm{plant} / \mathrm{ha} / \mathrm{yr}$ ). This was followed by a period
(1991 to 1994) with no recruitment. We did not register any disturbances associated with these 2 periods. The 1980 fire scars were found in $41 \%$ of the samples individuals $>13$ years of age.

Similar periods of recruitment were defined for Site 2, but with a temporal displacement associated with differences in manage ment (Fig. 1B). A low recruitment was observed in the first period, which coincided with logging activities and the heavy grazing by sheep ( $7.5 \mathrm{plant} / \mathrm{ha} / \mathrm{yr}$ between 1939 to 1961$)$. The second period included an impressive recruitment increase $(95.3$ plant/ha/yr between 1962 to 1965), which coincided with the extremely high cattle stocking rate at this site. Recruitment decreased again, but remained higher than in the first period $(16.2$ plant/ha/yr during 1966-1975). As at Site 1, the fourth period was characterized by enhanced recruitment ( $50.8 \mathrm{plant} / \mathrm{ha} / \mathrm{yr}$, between 1976 to 1985), and was followed by a period with no recruitment that corresponded with the introduction of rotational grazing practices (1986 to 1994).

The age structure of aerial parts at Site 1 showed a remarkable increase in the frequency of the younger classes, compared with the age of genets (Fig. 2A and 2B). We suggest that this change was driven by fire disturbances, because $90 \%$ of the vegetative regeneration registered occurred after the 1980 fire event. At Site 2 , resprouting stimuli such as fire or clearing also appear to have rejuvenated the stand though not as strongly as at Site 1 . In this case, no peak of resprouting appeared but the frequency of younger age classes was slightly greater compared with the ages of genets (Fig. 3A and 3B).

\section{Disturbances and Population Dynamics}

Recruitment showed variability between years, which enabled inferences to be made about the probable relationship between population dynamics and landscape disturbance (Fig. 1). Changes in recruitment coincided fairly well with management practices in both fields, particularly with the shift between sheep and cattle raising, which affected seed dissemination. Because the sampling method used does not quantify mortality rates directly, it was difficult to evaluate the effect of fire in wood clearing. Results suggested, however, that fire did not have a negative effect on seedling establishment. Recruitment at Site 1 showed no decrease (17.1 and $28.3 \mathrm{plant} / \mathrm{ha} / \mathrm{yr}$ respectively) in 7 year periods before and after the 1980 fire event. The concordance between fire and changes in the structural pattern of calden population through increased stem sprouting was evident at this site. At Site 2, the fire in 1964 coincided with the introduction of cattle, and produced an impressive peak of recruitment. However, the structural pattern was affected by logging activity. We found old trees, with stumps cut aboveground as required by former local laws. These had vigorous sprouts regeneration, generated around the time of tree felling.

In spite of marked variations between yearly values of precipitation on both sites, no relationships were found between annual or seasonal precipitation and population dynamics.

\section{Discussion}

The retrospective approach used in this study proved to be accurate enough to relate patterns and processes in $P$. caldenia populations. Even if the concordance found between population pattern and disturbance does not imply causal relationship in all 


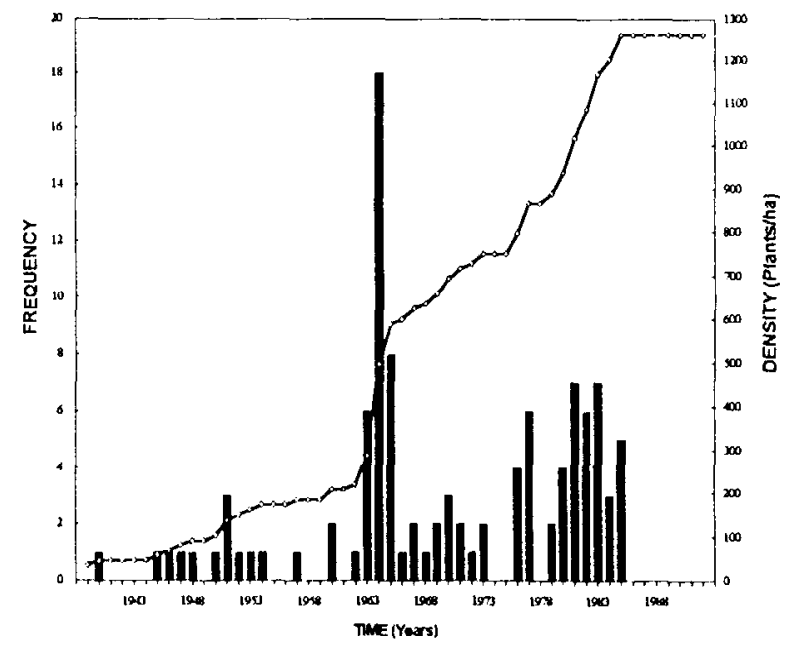

(1)

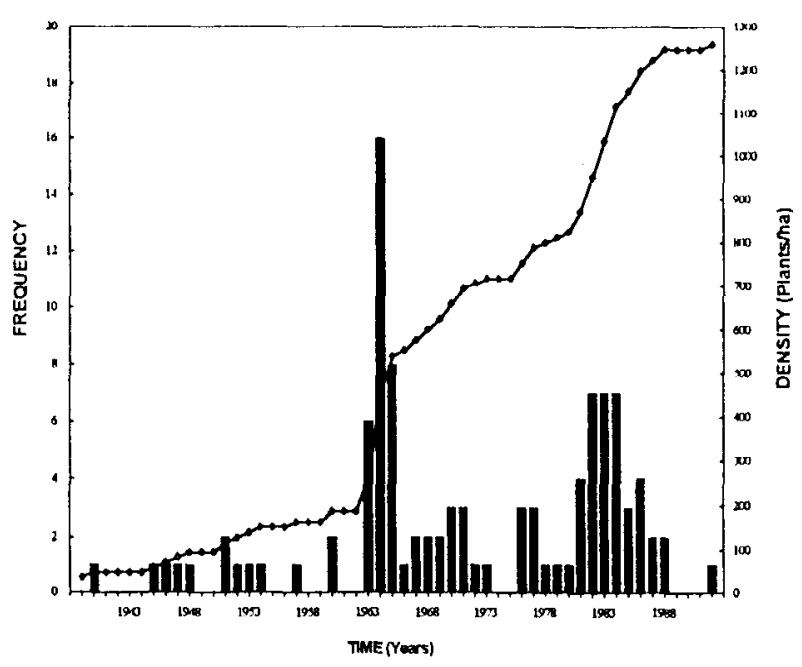

Fig. 3. Density (line) and frequency (bars) of age of establishment (A) and age of aerial part (B) of Site 2.

cases, it provides strong evidence to support some hypotheses. Retrospective studies are useful to examine the effects of infrequent events and slow processes, which cannot be assessed after then by costly long-term ecological studies. Further, retrospective studies support short-term experimentals by enabling sensible interpretation of the mechanistic studies to be made and modelling to be undertaken (Glenn-Lewin and Van Der Maarel 1992, Davis 1987).

The method we applied assumed that mortality produced no significant changes in the relative proportion of each cohort, and that recruitment was the major event determining the age structure of populations. The low number of dead in situ individuals and the high percentages of resprouting plants registered at both sites were taken as evidence of low tree mortality. Nevertheless, it should be noted that calden seedlings suffer high mortality rates a few weeks after emergence (Pelaez et al. 1992). This agrees with our 2 years of observations on calden seedlings survival that had naturally established in the forest (R. Peinetti et al., unpub- lished data). $P$. caldenia seedling emergence is clearly a much more frequent event than survival until the next growing season.

An important change in the semiarid Pampean region occurred with the introduction of livestock. This region had not been grazed by large herbivores since the end of the Pleistocene period (Bucher 1987). The history of range management is quite similar across the entire region (Colombato 1995), and particularly at the 2 sites chosen for the study. Sheep grazing was pervasive during the first half of this century in the calden forest and neighboring landscapes, and was later replaced by cattle grazing, due to local economy factors. This was the case at both sampled sites, with some temporal displacement in range management decisions. Despite that, woody population dynamics followed the changes in range management in a similar way at both sites. While sheep farming was not associated with increases in calden densities, high recruitment of calden occurred following the introduction of cattle. A similar response was inferred by Fisher (1959, as cited in Bahre and Shelton 1993) for velvet mesquite, in Texas, from feeding ewes and yearling steers with mesquite pods. He found that sheep effectively dispersed only $4 \%$ of the consumed seeds, whereas cattle dispersed $55 \%$ of them. Similar differences in plant establishment could have also occurred in our study. Old timers report that sheep are more likely to eat young seedlings than cattle. The reason cattle disperse more $P$. caldenia seeds than sheep is due to the greater consumption of fruits which are a highly palatable, valuable livestock forage (Menvielle and Hernandez 1985). When fruits are not consumed, seeds remain inside the indehiscent endocarp, which delays germination at the imbibition phase because of the endocarp and the hard seed coat (Peinetti et al. 1992). However, when ingested by cattle, germination is increased because the seeds are both separated from the endocarps and scarified when excreted (Peinetti et al. 1993). Effects of increased longevity in the soil bank have also been hypothesized, as livestock may disperse consumed seeds to places where they would otherwise be unlikely to arrive, e.g. away from host-specific predators harbored by parent plants (Lerner and Peinetti 1996). Indirect effects of cattle grazing by reducing grass competition may also aid woody weed invasions. However, evidence of these effects was not found in calden (Pelaez et al. 1992), nor in Texas honey mesquite, although seedling emergence was 7 to 8 times greater with defoliation of herbaceous vegetation regardless of grazing history, for this latter species (Brown and Archer 1989).

Fire is an important disturbance factor that regulates the balance between herbaceous and woody plants in many semi-arid savannas (Westoby et al. 1989, Bahre and Shelton 1993) through 2 separated effects on the woody population: (1) the control of population density, and (2) changes in structural patterns of growth. Fire may stimulate implantation rates by triggering dormant seed germination or by reducing competition within the community (Keeley 1987). Changes in structural pattern of growth occur when fire does not remove the individuals but only kills the woody topgrowth, thereby stimulating regrowth from stem bases. Fires are a common event in the caldenal forest and adjacent areas, arising from thunderstorms (lightening) or, more commonly, from poorly controlled fires. Controlled fires are used in La Pampa as a management practice to enhance palatable shortgrass productivity, and/or to control woody plants. However, the effect of fire on the dynamics of woody plant populations is not wholly understood. It is generally accepted that fire changes the structural characteristics of the $P$. caldenia population from 
woodland to shrubland but does not have a significant effect on mortality rate because of the capacity of individual plants to respruut when aerial parts die (Llorens 1995). On the other hand, the encroachment of $P$. caldenia over its current geographical range is partially explained as a consequence of a decrease in the frequency and intensity of fires (Distel and Boo 1995). A similar hypothesis was made to explain the ingress of $P$. velutina into grasslands (Bahre and Shelton 1993). This is not supported by the results shown in this paper, where fire did not reduce the establishment rate at either site.

Most savannas (particularly those in Africa) owe their existence more to the inpact of fire and large herbivores than to climate (Skarpe 1992). However changes in the level of precipitation, with dry and wet periods, are included among possible causes of shifts from savanna grasslands to woodlands (Westoby et al. 1989. Archer 1990, Bahre and Shelton 1993). Germination and seedling establishment are the most fragile stages of the calden life cycle and both processes are thought to depend, at least partly, on a combination of micro-scale climatic events. In our study, however, no relationship was found between plant establishment and precipitation. It is possible that our precipitation data are not an adequate measure of the moisture conditions encountered in the study site. Similar results were found with velvet mesquite in Southeastern Arizona: mesquite increases showed no clear relationship with variation in either annual or seasonal precipitation (Bahre and Shelton 1993). Archer (1989) found, however, that the development of woody plant communities dominated by honey mesquite, in a field grazed by cattle in the Rio Grande plains of Texas, was highly punctuated by wet and dry periods, occurring over a 20 year span.

The results showed that livestock grazing was the most important determinant of succession from a grassland or a savanna to a woodland, among the analyzed factors. This study therefore showed in a direct way the role of management practices, which are sometimes inferred by experimental trials at much lower temporal scales.

\section{Literature Cited}

Archer, S. 1989. Have southern Texas savannas been converted to woodland in recent history? Amer. Nat. 134:545-561.

Archer, S. 1990. Development and stability of grass/woody mosaics in a subtropical savanna parkland, Texas, USA. J. Biogeography.17:453-462.

Archer, S. 1995. Tree-grass dynamics in a Prosopis-thornscrub savanna parkland: Reconstructing the past and predicting the future. Ecosci. 2:83-99.

Archer, S., C. Scifres, and C.R. Bassham. 1988. Autogenic succession in a subtropical savanna. Ecol. Monog. 58:111-127.

Bahre, C.J. and M.L. Shelton. 1993. Historic vegetation change, mesquite increases, and climate in southeastern Arizona. J. Biogeography. 20:489-504.

Begon, M., J.L. Harper, and C.R. Townsend. 1990. Ecology-Individuals, Populations and Communities, second edition. Blackwell Scientific Publ., Massachusetts. p. 122-158.

Brown, J.R. and S. Archer. 1989. Woody plant invasion of grasslands: Establishment of honey mesquite (Prosopis glandulosa var. glandulosa) on sites differing in herbaceous biomass and grazing history. Oecologia 80: 19-26.

Bucher, E.H. 1987. Herbivory in arid and semi-arid regions of Argentina. Revista Chilena de Historia Natural 60:265-273.

Cano, E., B. Fernández and M. Montes. 1980. Vegetación, p. 77-78. In: Inventario Integrado de los Recursos Naturales de La Provincia de La Pampa (In Spanish). INTA, Provincia de La Pampa, Universidad Nacional de La Pampa. Buenos Aires.
Cabrera, A.L. and A. Willink. 1973. Biogeografía de América Latina (In Spanish). Serie Biología. Monogr. 13. Organization of American States, Washington DC. p. 69-76.

Casagrande, G. and H.A. Conti. 1980. Clima, p. 19-32. In: Inventario Integrado de los Recursos Naturales de La Provincia de La Pampa (In Spanish). INTA. Provincia de La Pampa, Universidad Nacional de La Pampa. Buenos Aires.

Colombato, J.A. 1995. La quimera del Trigo, p. 49-123. In: Trillar era una fiesta. Poblamiento y puesta en producción de La Pampa territoriana (In Spanish). Tomo I. Instituto de Historia Regional. Univ. Nac. de La Pampa. Argentina.

Cuttam, G. and J.T. Curtis. 1956. The use of distance measures in phytosociological sampling. Ecol. $37: 451-460$.

Davis, M.B. 1987. Retrospective Studies, p. 72-81. In: G. E. Likens (ed.), Long-Term Studies in Ecology. Springer-Verlag, New York.

Distel, R.A. and R.M. Boo. 1995. Vegetation states and transitions in temperate semiarid rangelands of Argentina, Vol 1: 117. In: Proc. 5th International Rangelands Congress. Salt Lake City, Ut.

Flinn, R.C., S. Archer, T.W. Boutton, and T. Harlan. 1994. Identification of annual growth rings in an arid land woody plant. Prosopis glandulosa. Ecol. 75:850-853.

Glenn-Lewin, D.C. and E. Van Der Maarel. 1992. Patterns and processes of vegetation dynamics, p. 11 59. In: D. C. Glenn Lewin, R. K. Peet and T. T. Veblen (eds), Plant succession: Theory and Prediction. Chapman \& Hall, London.

Harper, J.H. 1990. Population Biology of Plants, 8th edition. Academic Press. San Diego, Calif. p. 599-647.

Keeley, J.E. 1987. Role of fire in seed germination of woody taxa in California chaparral. Ecol, 68:434-443.

Kershaw, K.A. 1973. Quantitative and Dynamic Plant Ecology, second edition. Edward Amold, London. p. 128-145.

Lerner, P. and R. Peinetti. 1996. Importance of predation and germination on losses from the seed bank of calden (Prosopis caldenia). J. Range Manage. 49:147-150.

Llorens, E.M. 1995. Viewpoint: The state and transition model applied to the herbaceous layer of Argentina's calden forest. J. Range Manage. 48:442-447.

Matteucci, S.D. and A. Colma. 1982. Metodología para el estudio de la veg. etacíón (In Spanish). Serie Biologia Monogr. 22. Organization of American States, Washington DC. p. 38-44.

McNaugthon, S.J. 1992. The propagation of disturbances in savannas through food webs. J. Veg. Sci. 3:301-314.

Menvielle, E.E. and O.A. Hernandez. 1985. El valor nutritivo de las vainas de calden (Prosopis caldenia Burkart) (In Spanish). Revista Argentina de la Producción Animal 35:548-550.

Nazar Anchorena, J.B. 1988. Pastizales Naturales de La Pampa. Manejo en regiones semiáridas (In Spanish). Convenio AACREA. Provincia de La Pampa. p. 83-88.

Peinetti, R., E. G. Dussart, and J.A. Boninsegna. 1994. Análisis dendrocronológico preliminar de la tendencia de edad en calden (Prosopis caldenia (L) Burk.), p. 877. In: Proc. International Meeting of the IAWA. Mar del Plata. Argentina.

Peinetti, R., C. Cabeza, M. C. Pereyra, and O. Martinez. 1992. Observaciones preliminares sobre la diseminación del caldán (Prosopis caldenia Burk.) en la region semiárida de la Argentina (In Spanish). Turrialba 42:415-417.

Peinetti, R., M.C. Pereyra, A. Kin, and A. Sosa. 1993. Effects of cattle ingestion on viability and germination rates of calden (Prosopis caldenia) seeds. J. Range Manage 46:483-486.

Pelaez, D.V., R.M Bo, and O.R. Elia. 1992. Emergence and seedling survival of calden in the semiarid region of Argentina. J.Range Manage. 45:564-568.

Salazar Lea Plaza, J.C. 1980. Geomorfología, p.32-38. In: Inventario Integrado de los Recursos Naturales de La Provincia de La Pampa (In Spanish). INTA, Provincia de La Pampa, Universidad Nacional de La Pampa. Buenos Aires.

Skarpe, C. 1992. Dynamics of savanna ecosystems. J. Veg. Sci. 3:293-300.

Villalba, R. 1985. Xylem structure and cambial activity in Prosopis flexuosa DC. IAWA Bull. n.s. 6: 119-130.

Walker, B.H., Ludwing, D., Holling, C.S., and R.M. Peterman. 1981. Stability of semi-arid savanna grazing systems. J. Ecol. 69:473-498.

Westohy, M., B. Walker, and Y. Noy-Meir. 1989. Opportunistic management for rangelands not at equilibrium. J. Range Manage. 42:266-274.

Young, J.A. and R.A. Evans. 1981. Demography and fire history of a western juniper stand. J. Range Manage. 4:501-506. 